\title{
Cenozoic tectonic evolution of the northern Apulian carbonate Platform (southern Italy)
}

\author{
Angela Vita Petrullo (1), Fabrizio Agosta (1), Giacomo Prosser (1), Enzo Rizzo (2)
}

\section{ABSTRACT}

A 3D geological modeling of a large portion of the Apulian Platform buried underneath the Bradano Trough, southern Italy, is carried out by integrating 2D seismic reflection profiles, well log data, and published top Apula isobaths. The results of this work highlight the presence of five sets of high-angle, km-long faults, which displace the topmost units of the Apulian Platform. Both timing and kinematics of faulting are investigated by considering age, distribution, and thickness of the Cenozoic sedimentary terranes topping the Mesozoic Apulian carbonates.

The study area is characterized by a major fault scarp made up of NW-SE and NNW-SSE fault segments. This structural feature shows a Messinian-Early Pliocene transtensional kinematics, which might have occurred on pre-existing structural heterogeneities. On the contrary, on the basis of their abutting and crosscutting relationships with respect to the aforementioned fault zone, a Pliocene-Quaternary age is inferred for the N-S and NE-SW trending extensional faults, and an Early Pliocene age for the extensional NNE-SSW trending faults. These results are discussed in light of the complex tectonic evolution of the Central Mediterranean area, and may contribute to better assess the structural evolution of the fault network that dissects the northernmost portion of the Apulian Plate, at the boundary with the Adria Plate.

KEYwORDS: Apulian Platform, high-angle faults, 3D geological modeling, Adria-Apulia plate boundary.

\section{INTRODUCTION}

The Adriatic Carbonate Platform is one of the largest Mesozoic carbonate platforms of the Mediterranean region confined by Tertiary-Quaternary collisional belts (DERCourt et alii, 1986). It represents the emerged portion of a relatively rigid crustal sector, named Adria or Adriatic microplate, for the most part extending beneath the Adriatic sea (CHANNEL et alii, 1979; ANDERSON \& JACKSON, 1987). It is partly buried beneath foreland basins relative to the non-coeval, opposite-verging orogenic systems, of the NE-verging Apennine (westward) and SW-verging Dinaric-Hellenic (eastward) fold-and-thrust belts (DE AlteriIs, 1995).

One of the latest tectonic reconstructions of the Mediterranean area (SchetTino \& TuRco, 2011) assumes that Adria is divided in two microplates, Adria and Apulia, separated by means of a major tectonic boundary affecting the continental lithosphere since the Late Cretaceous

(1) Dipartimento di Scienze, Università degli Studi della Basilicata, Viale dell'Ateneo Lucano 10, 85100 Potenza, Italy. Corresponding author e-mail: angelav.petrullo@gmail.com.

(2) Istituto di Metodologie per l'Analisi Ambientale, CNR, C. da S. Loja, 85050 Tito Scalo (Pz), Italy. times. Movements along the inferred Adria/Apulia plate boundary were driven by the relative motion between the African and the Eurasian plates. From the Early Cenomanian ( 100 Ma) to Late Eocene ( 40 Ma), Africa assumed northward migration, producing further left-lateral slip along the Adria/Apulian plate boundary. Geological evidence for the existence of such a regional tectonic lineament can be found in the present Mattinata Fault Zone, which is a $150-\mathrm{km}$-long, E-W-trending structural element cutting across the Gargano Promontory and the southern Adriatic Sea. Salvini et alii (1999) and Brankman \& Aydin (2004) showed that the Mattinata Fault Zone solved in the geological past left-lateral, strike-slip kinematics with later-re-activation as a dextral, strike-slip fault from Middle Pleistocene times (Tonde et alii, 2005). According to ARGNANI et alii (2009), the movements along the Mattinata Fault Zone started during Tertiary times, producing extensive fracturing of the Early Cretaceous limestone rocks.

During Tertiary times, the Adria Plate was partly involved in the orogenesis of the Dinarides, to the east, and of the Southern Apennines, to the west. In addition, due to the Dinaric-Hellenic orogenic system, strike-slip tectonics locally associated with either contractional or extensional deformation structures occurred in the Southern Adriatic Basin (De Alteriss, 1995; Bertotti et alii, 1999; Casolari et alii, 2000; BILLI et alii, 2007). The structural setting of the Apulian Platform is therefore rather complicated, because it represents a zone of interaction between neighboring opposite-verging chains. Aiming at unraveling the tectonic evolution of the Apulian Platform, the present contribution focuses on the tectonic structures affecting a significant portion of the foredeep-foreland domain of the Southern Apennines, Italy. There, the Apulian Platform consists of Jurassic-Upper Cretaceous, shallow-water carbonates unconformably covered by Cenozoic deposits (RicchetTI et alii, 1988; CIARANFI et alii, 1988). While the latter ones are not very common in the fore-bulge area, they are quite voluminous more westward where the foreland plunges below the Pliocene-Pleistocene infill of the Bradano Trough, the most recent foredeep of the Southern Apennines (MARIOTTI \& Doglioni, 2000). The depositional setting of the Apulian Cenozoic sedimentary succession was partially affected by a syn-sedimentary tectonic activity, which controlled both location and evolution of the depocenters. For this reason, we first analyzed both geometry and composition of the Cenozoic deposits by means of well log and seismic reflection profiles interpretations, then the 3D geological modeling of an about $2,000 \mathrm{~km}^{2}$ area was computed to decipher the large-scale architecture of the fault network. The results of this work are discussed in light of the existing bib- 


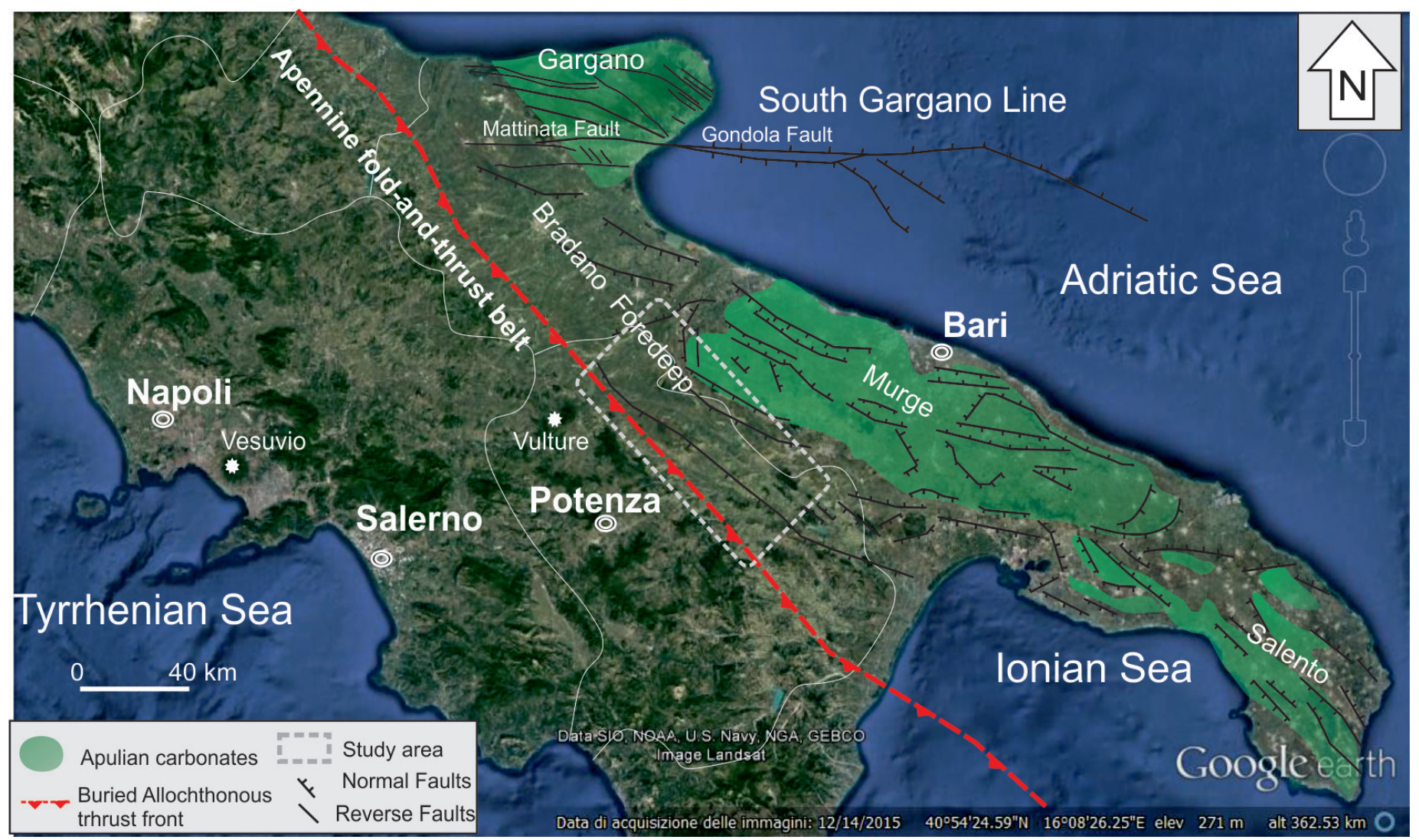

Fig. 1 - Geological sketch of the foredeep-foreland domain of Southern Apennines chain (modified after BRANKMAN \& Aydin 2004; PIERI et alii, 1997). The dashed grey box represents the study area.

liography to assess both ages and kinematics of the aforementioned fault network. Hence, the results provide useful information to better constrain the tectonic evolution of the Central Mediterranean area (CHANnEl \& HoRvath, 1976; Patacca et alii, 1990; Schettino \& Turco, 2011; Turco et alii, 2012), and fuel new studies on the architectural and petrophysical properties of the individual fault sets, which may profoundly impact both migration and storage of geofluids in the shallow crust (PEACOCK et alii, 1998; Agosta, 2008; Agosta et alii, 2008).

\section{GEOLOGICAL SETTING}

The Apulian carbonate Platform is widely exposed in Gargano, Murge and Salento areas of southern Italy, and forms part of the present foreland domain of the Dinaric-Hellenic and southern Apennines fold-and-thrust belts (Ricchetti et alii, 1988; Argani et alii, 1993; De Alteriss \& AIELLO, 1993). During the Neogene, large sectors of Apulian Platform were progressively involved in the foredeep and foreland areas of the Apenninic and Dinaric-Hellenic orogens (Ricchetri et alii, 1988). The Dinarides is a SW-verging, fold-and-thrust belt whose main stages of deformation took place during the Eocene-Oligocene, when shortening mainly produced thrusts and folds (DIMITRIJEVIĆ, 1997; PAMIC et alii, 1998 and references therein). Continued, post-early Miocene deformation of the Adria paleomargin took place in the Albanian chain and in a narrow, elongated, SW-verging imbricate belt located at the front of the
External Dinarides, which extended from the NE edge of the Istria peninsula southwards, across the coastal islands and in the Adriatic offshore (Scisciani et alii, 2009). The Apennines is a E- to NE-verging, fold-and-thrust belt that developed from the Oligocene time onward in response to the relative motions of the European and African plates (DEwey et alii, 1989). The Southern Apennines formed by piggy-back propagation of E- to NE-verging thrust sheets, which gradually deformed the pre-existing Mesozoic shallow- and deep-water sedimentary sequences stratigraphically overlain by Neogene units (SCANDONE, 1972; D'ARGENIO et alii, 1973; Pescatore, 1978; Mostardini \& Merlini 1986; CEllo et alii, 1989, 1990). Miocene-to-Pleistocene foredeep and thrust-top basins developed during the progressive eastward propagation of contractional deformation (PATACca et alii, 1990; Patacca \& Scandone, 2001).

Focusing on the Apulian Platform, its western margin was affected by a rapid subsidence due to the eastward rollback of the Adriatic subduction hinge (MALINVERNo \& RYAN, 1986; Doglioni et alii 1996), with formation of the deep-water, depocenters infilled with turbiditic siliciclastic deposits during the Messinian-to-Pleistocene times (Mostardini \& Merlini, 1986). In the Late Pliocene, a continuous foredeep basin developed in front of the Apennine mountain chain from the Po Valley to Southern Basilicata. In the Southern Apennines, the southern part of this basin, the Bradano Trough, experienced flexural subsidence until the Early Pleistocene-Middle Pleistocene boundary when a sudden drastic change in the tectonic regime took place. In this time interval, the mountain chain under- 
went a generalized uplift together with the foredeep basin (Patacca \& Scandone, 2007). In the study area, located in foredeep-foreland domains of the Southern Apennines chain between the Vulture Volcano and the Murge Plateau (Fig. 1), the western edge of the Apulian Platform is covered by Pliocene foredeep deposits, which in turn are overthrusted by the Apennine tectonic units of the accretionary wedge.

\section{STRATIGRAPHY}

The Apulian carbonate Platform consists of rocks that formed in a wide range of depositional environments, from evaporitic basins to deep, open platforms (Fig. 2). Starting from the Paleogene, both Apulia and the present-day southern Adriatic Sea areas underwent a general uplift and subaerial exposure, as documented by the widespread unconformity topping the Cretaceous carbonates (BosELLINI et alii, 1999). In most places, the oldest Tertiary deposits are of Eocene age (VLAHOVIC et alii, 2005); during that time, limestones with Nummulites ("Calcari a Nummuliti") and calcareous breccias ("Brecce di Lavello") were deposited on top of the Cretaceous carbonates (MigLiorini, 1944; SElla et alii, 1988). These deposits were connected to an emersion phase, Lutetian in age, which induced the erosion of the carbonate platform and the consequent production of breccias. A feature present within of the Eocene deposits is the local presence of volcanic rocks, which consist of both tuffs and basalts, forming either distinct levels or as clasts within polygenic breccias. A regional-scale regression took place at the end of the Eocene, which determined a lack of Oligocene sediments throughout the area (SELLA et alii, 1988).

Lower and Middle Miocene sediments were again deposited in a carbonate shelf environment affected by significant terrigenous inputs (SELLA et alii, 1988). The San Ferdinando Formation consists of calcareous breccias, which unconformably cover both Eocene and Cretaceous carbonates, whereas the carbonate packestones and wackestones of the Bolognano Formation lies on a paraconformity topping the San Ferdinando Formation (CRESCENTI et alii 1969; RicchetTI et alii, 1988). During Messinian times, large evaporitic basins developed in this area, as in the whole Mediterranean Sea (Roveri et alii, 2001), causing the formation of the pre-to-post evaporitic facieses of the Gessoso-Solfifera Formation (CRESCENTI et alii 1969).

During the Lower Pliocene, sea water flooded the Bradano Through and marine conditions persisted until the Early Pleistocene (SELLa et alii, 1988). The Plio-Pleistocene deposits form a single sedimentary sequence recording a transgressive-regressive episode (AzZAROLI, 1968; BALDUZZI et alii 1982b). The Pliocene basal conglomerate/ sandy complex and the shallow-marine carbonate deposits pertaining to the Gravina Calcarenites (AzzARoLI, 1968) recorded the transgressive stage of infilling, and were overlain by Pleistocene silty-clay hemipelagic deposits of the Sub-Apennine Clays Unit (AzzAroli, 1968), which is the upper portion of a thick sequence filling the Bradano Trough (Patacca \& Scandone, 2007). In turn, the regressive stage was recorded by the marine and/or continental terraced deposits found around the whole Apulia region (VEzZANI, 1967; CiaranFi et alii, 1992).

Tectonic emplacement of an allochthonous thrust sheet, pertaining to the frontal part of the Apennine fold-

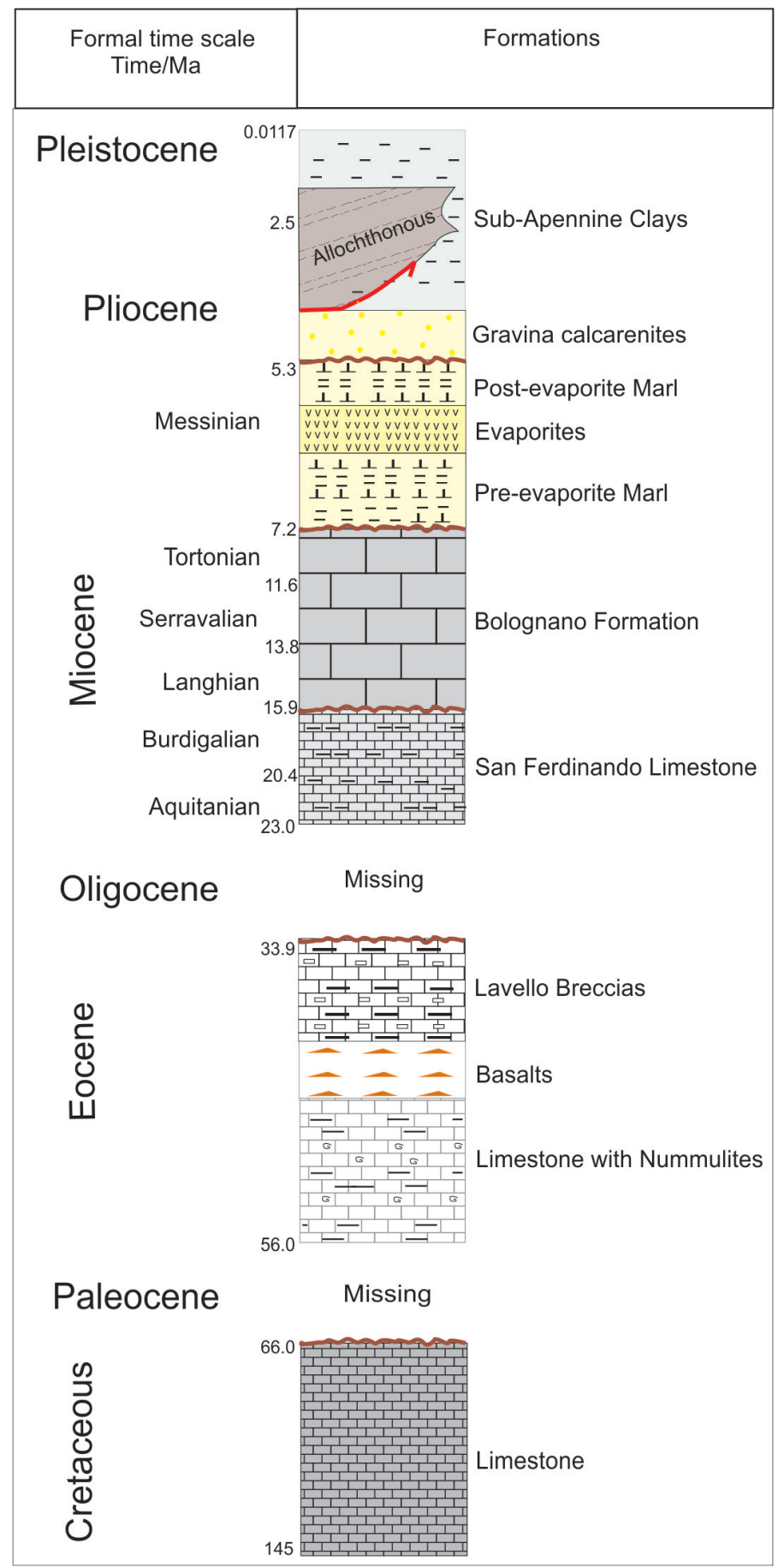

Fig. 2 - General stratigraphic column (not to scale) recognized in exploration wells showing Apulian Platform succession and the relative covers.

and-thrust belt, affect the western side of the Bradano Through. The thrust sheet tectonically covered the top levels of the Apulian Units in the inner sector of the Bradano Trough, and the Middle-Late Pliocene deposits in its more external areas (CARISSIMO et alii 1962; MostardinI et alii 1966; Sella et alii 1988; Mostardini \& Merlini 1986). The thrust sheet is represented by a complex tectonic assemblage of Mesozoic and Tertiary sedimentary units, hereafter referred as Allochthonous Complex (MostaRdini \& MERLINI, 1986). 


\section{TECTONICS}

The Apulian foreland extends from the Apennines thrust front to the Adriatic coast. The autochthonous units of the foreland are exposed in the Gargano, Murge and Salento areas, separated by transversal morpho-structural depressions (Funiciello et alii 1988; RicCHetTI et alii 1988; PIERI et alii 1997). The same units underlie the Allochthonous Complex and the Plio-Pleistocene marine deposits of the Apennine foredeep (CASERo et alii, 1988). A major NWSE to NNW-SSE striking normal fault set marks the transition from the forebulge to the Bradano Trough (FAvali et alii, 1990, SElla et alii, 1988; Fig. 1). Such a fault set is thought to be due to the foreland response to the northeastward thrusting of the Apennine chain (DEL GAUdio et alii, 2007).

These NW-SE trending normal faults have been documented in the Murge Plateau and in the eastern Bradano foredeep area. Here, syn-tectonic deposits lying at the fault hanging walls suggest that these structures were likely active during the Plio-Pleistocene times (TROPEANO et alii, 1994), but also during Cretaceous (PIERI \& LAVIANO, 1989; Festa et alii, 2003) and Miocene times (Iannone \& Pieri,
1982; CiARANFI et alii, 1983; Funiciello et alii, 1991; GAMBINI \& Tozzi, 1996). Furthermore, Quaternary normal faults and related graben are documented all over the Murge Plateau and display different orientations (NW-SE, SW-NE, E-W, N-S and NNW-SS) (Iannone \& Pieri, 1982; Tropeano et alii, 1997).

Other important tectonic elements are represented by the Gargano Fault System, which affects the Mesozoic carbonates succession of the Gargano Promontory and consists of NW- to W-striking folds, thrusts, and left-lateral transpressional and strike-slip faults. Within this fault system, the Mattinata Fault in the southern Gargano Promontory is the most prominent fault (OrTolani \& Pagliuca, 1987; Funiciello et alii, 1988; Salvini et alii, 1999; BRANKMAN \& AYDIN, 2004). The Mattinata Fault is an E-W-trending and about $50 \mathrm{~km}$ long structure that cuts the Gargano Promontory in the foreland of the Southern Apennines and its prolongation toward the east is considered the Gondola Line. The Gondola Line is located offshore at the eastern edge of the Mattinata Fault, trends E-W to NW-SE, and it is as long as $80 \mathrm{Km}$ (De AlteriIs \& Aiello, 1993; Morelli, 2002). The Mattinata Fault and the Gondola Fault Zone are neither directly connected nor perfectly aligned. Dif-

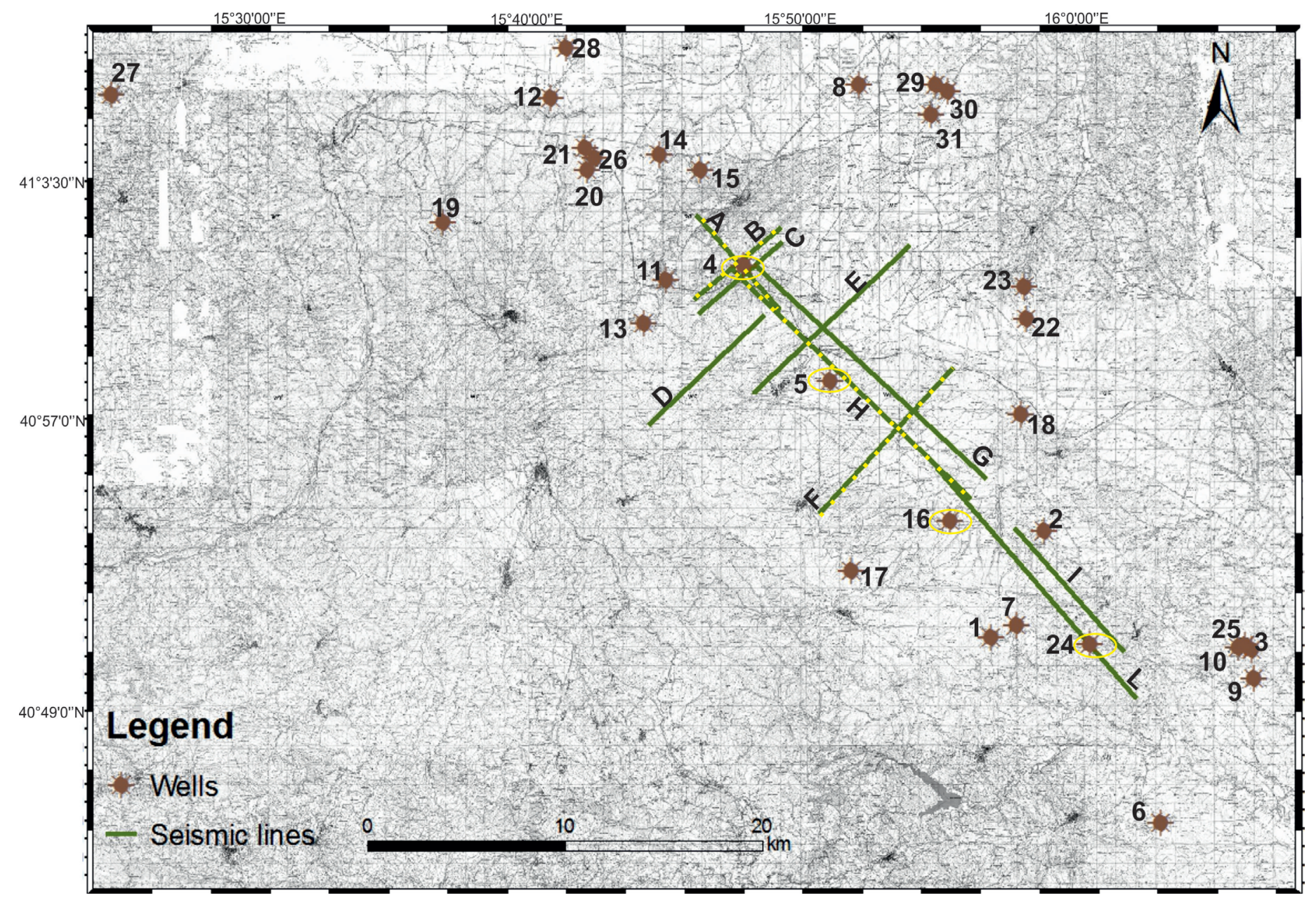

Fig. 3 - Well logs, isochron maps and seismic lines georeferenced by using a GIS platform. (Wells: 1-Agatiello1, 2 Arcieri, 3-Banzi, 4-Bellaveduta, 5-Calvino, 6-Donna Caterina, 7-Forenza2, 8-Gaudiano, 9-Genzano1, 10-Genzano2, 11-Lavello1, 12-Lavello2, 13-Lavello5, 14-Lavello4, 15-Lavello6, 16-Maschito1, 17-Maschito2, 18-Matinella1, 19-Melfi1, 20-Masseria Spavento1, 21-Masseria Spavento3, 22-Montemilone1, 23-Montemilone2, 24-Musacchio1, 25-Muscillo1, 26-Rendina1, 27-San Raffaele1Dir, 28-Serra Spavento6, 29-SpgnolettiB, 30-SpagnolettiC, 31-SpagnolettiD. Seismic sections: A-Pz 18-85, B-14-85, C-15-85, D-16-85, E-VN4, F-VN5, G-VN1, H-483-82, I-440-81, L-384-79). 
ferent interpretations exist on the kinematics and tectonic history of these two tectonic elements. The majority of the studies documented up to $5 \mathrm{~km}$ of left-lateral slip along the Mattinata Fault (Funiciello et alii, 1988; FaVAli et alii, 1993; Salvini et alii, 1999; Billi \& Salvini 2000; Brankman \& AYDIn, 2004; BILLI et alii, 2007), which was followed by a Pleistocene-to-present day right-lateral kinematics (CHILOVI et alii, 2000; Tond et alii, 2005; Monti et alii, 2005). Seismic reflection profiles-based studies carried out across the Gondola Line show predominant right-lateral kinematics (Guerricchio, 1983; FinetTi, 1984; De Dominicis \& Mazzoldi, 1987; Colantoni et alii, 1990; De Alteris \& Aiello, 1993; PiCCARDI, 1998) with possible left-lateral reactivation components (De Alteris, 1995; Morelli, 2002).

According to BERTOTTI et alii $(2009,2001)$, CASOLARI et alii (2000) and BiLLI et alii (2007), the analysis of outcropping, some syn-sedimentary structural elements are consistent with a Miocene-Pliocene contractional and transpressional activity along the Gargano Fault System, and its subsequent strike-slip deformation during Pleistocene times. BILli et alii (2007) proposed a regional tectonic model, in which the Gargano Fault System is linked with the tear faults that segmented the Apulian Platform. According to the letter authors, the strike-slip kinematics solved by the aforementioned fault system was due to the non-cylindrical evolution of the Apulia slab beneath the Apennines fold-and-thrust belt. Differently, BRANKMAN \& Aydin (2004) recognized the Gargano Promontory as a push-up block bounded by two regional-scale, E-W-trending, right-stepping, left-lateral, strike-slip fault zones. Such a structural configuration, produced NW-striking, reverse faults in the Apulian Platform, which was therefore involved in a compressional stress field localized within the constructional jog.

\section{AVAILABLE DATA AND METHODOLOGY}

3D modeling has been performed using different types of data obtained from the archives of the Italian Ministry of Economic Development (http://unmig.sviluppoeconomico.gov.it, namely the ViDEPI project). The first step consisted in the collection, selection and revision of all available data, which includes geological maps, geological cross-sections, well composite logs, stratigraphic columns, isochron maps and seismic profiles. In order to manage, interpolate and spatially correlate all information derived from the aforementioned database, the available data have been geo-referenced according to a common geographical system (WGS 1984) by using a GIS platform (Fig. 3). A set of about 31 well composite logs has been used to build the stratigraphic framework of the study area. Whenever possible, wells have been tied to seismic profiles in order to set stratigraphic constraints.

\section{WELL LOGS}

In analyzing the composite logs (VIDEPI Project), the following aspects had to be taken into account: 1) inhomogeneous quality in stratigraphic information (part of the wells were cored during the late 1960's to 90's by several different oil companies); 2) sedimentological or paleontological detail is often missing; 3 ) the lithologic successions were subdivided by different operators adopting very dif- ferent criteria: lithostratigraphic units (formations), biostratigraphic units, chronostratigraphic units or facies units.

To overcome some of the above problems and to obtain reliable thickness variations, stratigraphic data from individual well logs have been re-interpreted focusing on the stratigraphic successions pertaining to the upper part of Apulian platform. A coherent stratigraphic subdivision has been adopted based on correlation of various lithostratigraphic charts and fossil contents indicated in the logs. Well logs were imported into Move ${ }^{\mathrm{TM}}$ software as text files containing the following information: $\mathrm{x}$ (Longitude), $\mathrm{y}$ (Latitude), z (Measured Depth), depth Top and Horizon type.

This allowed the use of the "Create surface from points" toolbox of Move ${ }^{\mathrm{TM}}$ software to generate surfaces from the imported well-tops. Since the exploration wells are mainly concentrated within the foredeep, whereas less information is available in other nearby areas, the isobath map of Nicolai and Gambini (2007) was digitized to provide further details.

\section{SEISMIC REFLECTION PROFILES}

Since the original seismic profiles were stored in raster format within the VIDEPI database, these have been converted into seg-y files in order to import them into the Move $^{\mathrm{TM}}$ software. This conversion was carried out using image2segy 2.2.6, a free Matlab tool developed by the Instituto de Cièncias del Mar (Spain), which allows the creation of a georeferenced seg-y file from a scanned seismic image. Since it was not possible to reprocess the raw seismic data, the quality of the original raster files was of primary importance in generating the seg-y file. Taking into account the base maps on Videpi (Fig. 4a), on each seismic line the first and last pixel, known as primary pixels, were identified with an accurate geographical positions (X, Y) because the trace length of the seismic section does not always correspond to the effective length of the seismic section. When the seismic lines changed direction in map view it was necessary to consider other primary pixels along the seismic traces in order to avoid distortion errors. Moreover, after seg-y conversion, the application of procedures aiming at attenuating lateral discontinuities and artifacts were neglected.

The seismic sections in SEG-Y format have been imported into Move ${ }^{\mathrm{TM}}$ software for the interpretation and digitization of horizons relative to the stratigraphic units of Apulian Platform and the Plio-Pleistocene sedimentary cover (Fig. 4b).

The top surface of the carbonate strata is characterized by a high-amplitude reflection, which results from the change in acoustic impedance between the Plio-Pleistocene siliciclastic cover and the underlying carbonate succession. The seismic data often report old interpretations and are of poor quality, especially beneath the top of the Apulia Carbonate Platform. However, in some places it was possible to appreciate the top Eocene and Miocene.

Faults and horizons were interpreted on the seismic sections and, where possible, all available well data were also uploaded to further constrain the interpretation. Then, a specific velocity values was attributed to each stratigraphic units, allowing a time-to-depth conversion with the Move $\mathrm{T}^{\mathrm{TM}}$ software. The velocity values of several horizons identified 

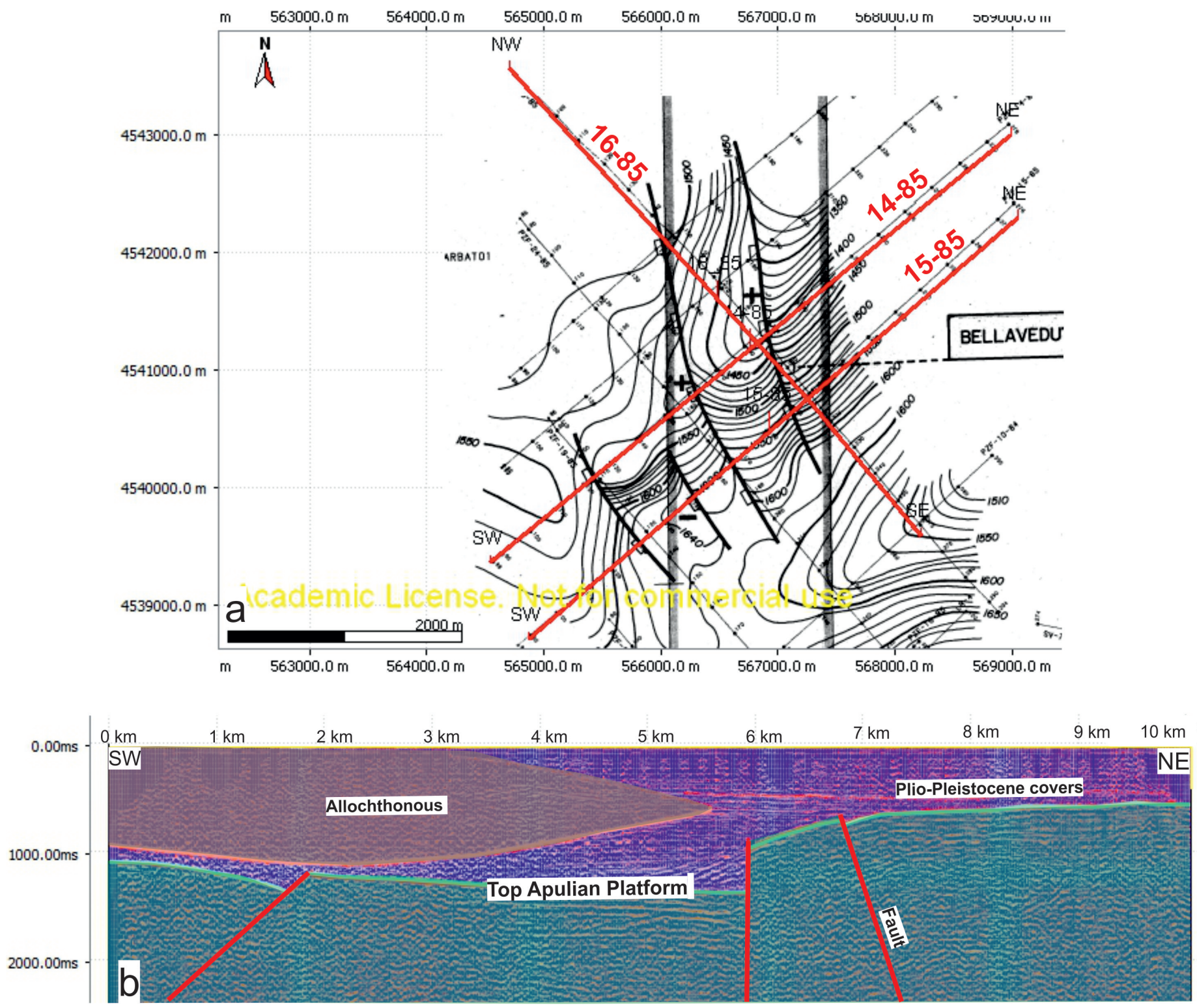

Fig. 4 - (a) Example of base maps (Aquilonia Permission) on Videpi used to georeference the seismic lines. (b) Example of a seismic interpretation of the VN5 seismic section, NE-SW oriented (from ViDEPI Project). See Fig. 3 for exact location.

in the seismic sections were calculated with "direct conversion time-depth method" considering the thickness of individual units recognized in well logs $(\mathrm{Z})$ and the corresponding TWT on the seismic section. This simple method uses constant velocity within the individual layers and does not take into account possible lateral variations of stratigraphic units. The average velocity, taking into account the correlation between deep well-logs and seismic section, was calculated according to the following equation:

$$
\text { Velocity= Z/(TWT/2) }
$$

The average velocity values calculated and used in the time-to-depth conversion of the sections are the following: Late Pliocene (Conglomerates) Middle Pliocene (Sands) Middle Pliocene (Clay) Middle Pliocene (Calcarenites) Early Pliocene Evaporitic Marl (Messinian)
$1781 \mathrm{~m} / \mathrm{s}$

$2763 \mathrm{~m} / \mathrm{s}$

$3112 \mathrm{~m} / \mathrm{s}$

$2949 \mathrm{~m} / \mathrm{s}$

$2599 \mathrm{~m} / \mathrm{s}$

$2621 \mathrm{~m} / \mathrm{s}$
Isochrons obtained from the available isochron maps of small portions of the study area were digitized as linear shapes with the associated time attribute (milliseconds) using a GIS software. Isochron data were then interpolated and converted to a raster by means of a TIN (Triangulated Irregular Network). GIS raster data were imported into Move $^{\mathrm{TM}}$ software as images and displayed in 3D view to better constrain the stratigraphic and structural features of the study area. Finally, a 3D model integrating the aforementioned data was developed by means of Move ${ }^{\mathrm{TM}}$ software.

\section{RESULTS}

3D Geological Modeling

3D geological modeling is carried out by integrating the aforementioned 2D seismic reflection profiles and well 

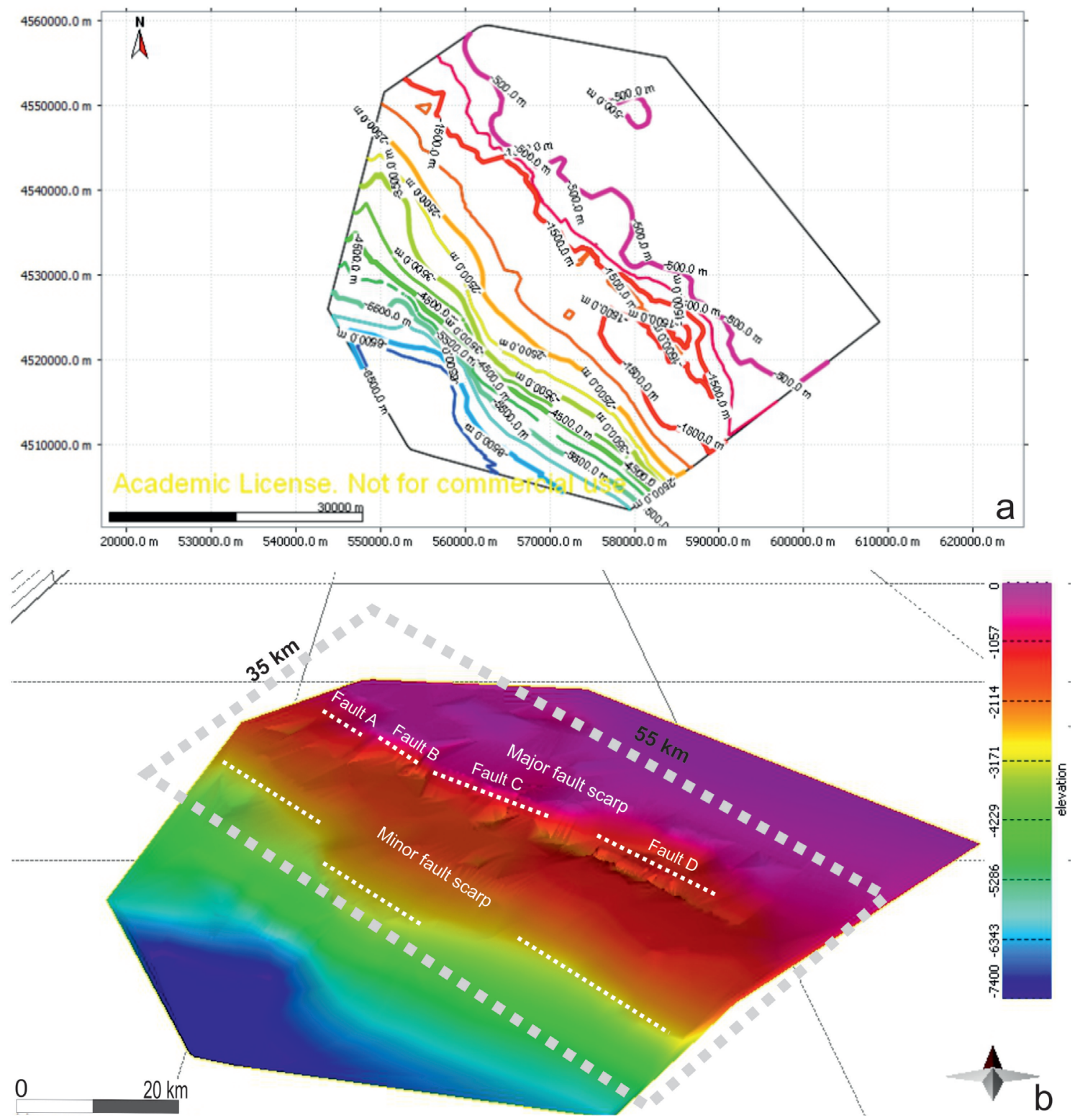

Fig. 5 - (a) 2D isobath map of Apulian Carbonates Platform. The isobath (every $500 \mathrm{~m}$ ) are referred to the Apula top surface (Upper Cretaceous to Messinian age); (b) 3D isobath map of top Apula surface showing two mainly fault scarp architecture obtained by 3D modeling of Top Apula surface. The legend bar on the right shows with different colors the surface elevation in meters. The dashed grey line represents the area investigated in more detail in figure 1. The isobhat map obtained after 2D seismic reflection and well log data interpretation, and by also taking into account the isobath map by Nicolai \& GambinI (2007).

logs, and by also taking into account the isobath map by Nicolai \& Gambini (2007). Such a work is first aimed at deciphering the geometry of the buried Top Apulian carbonates, which corresponds to the base of the Plio-Pleistocene sedimentary infill of the foredeep, unconformably covering the Apulian carbonates (PATACCA \& Scandone, 2007). Due to this unconformity, carbonates at the Top of the Apulian platform do not correspond to a specific stratigraphic unit and display an age range spanning from the Upper Cretaceous to the Messinian. On this regard, the 3D geological modeling focuses on the geometry of the Top Cretaceous, Top Eocene and Top Miocene chronostratigraphic surfaces, respectively. Then, the displacement of these known stratigraphic markers is used to assess the geological nature of the most prominent morphological scarps affecting the top Apulian carbonates. Finally, both timing and kinematics of the high-angle fault sets are investigated by taking into account the thickness distribution of both Miocene and Eocene formations and, of course, in light of their structural architecture.

\section{GeOMETRY OF THE Top ApUlian CARBonates}

The isobath map of figure 5 clearly shows a SW-dipping top Apula surface, whose buried western margin cannot be identified due to a lack of data. Nevertheless, the modeled 3D top Apula surface highlights two pronounced NW-SE trending morphological scarps, the major of which, already known in literature, is located along the eastern portion of the study area (SELLA et alii, 1988). The easternmost morphological scarp is characterized by a height of about $1 \mathrm{~km}$ and a length of about $55 \mathrm{~km}$, and results to include four, high-angle, individual fault segments (labeled from A to D, respectively, in Fig. 5). The NW-SE trending Fault A and Fault $C$ display a right-stepping geometry, and are linked together by the NNW-SSE trending Fault B; whereas the NW-SE trending Fault $\mathrm{C}$ and Fault $\mathrm{D}$ display a left-stepping geometry. The westernmost morphological scarp is a rather continuous feature that likely includes three main, high-angle, individual fault segments. The area comprised between the 


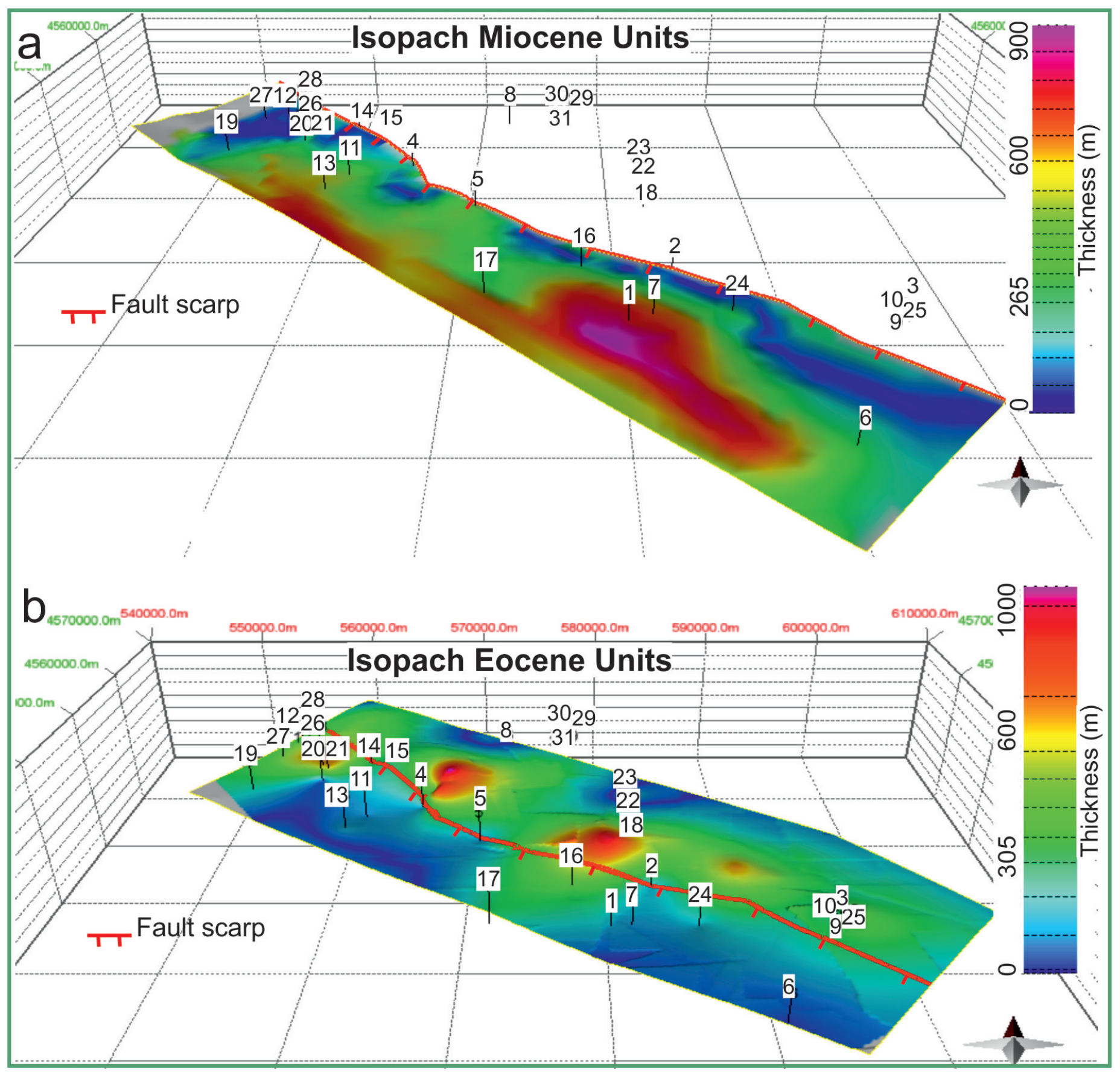

Fig. 6 - Thickness analysis of Top Miocene surface (a) (calculated between Top Miocene and Top Eocene) and Top Eocene surface (b) (calculated between Top Eocene and Top Cretaceous) in relation to fault scarp identify by continuous trace but made up by four fault segments.

two main aforementioned NW-SE trending fault zones is crosscut by smaller-scale, NNE-SSW trending morphological scarps that abut against the major ones.

In some cases, the stratigraphic units are not reported in well logs; so the study and comparison among the lithological descriptions and fossils content of several well logs allowed us to define them. For example, the lithological description reported in the Masseria Spavento3 well $\log$ (\#21 of Fig. 6b) enabled us to decipher the presence of a previously unreported Top Eocene surface. By recognizing the Top Miocene, Top Eocene and Top Cretaceous surfaces in the well logs and seismic profiles, the thick- ness variations of both Eocene and Miocene stratigraphic units is computed after the 3D geological modeling of the study area (Fig. 6a and 6b). The highly discontinuous Miocene deposit is present only at the hanging wall of the easternmost morphological scarp, and also shows a significant thickness change along the strike of the fault scarp (Fig. 6a). In particular, the westernmost portion of the study area rarely displays Messinian evaporites only within the Allochthonous Complex (Lavello5 and Agatiello1 wells, \#13 and \#1 of Fig. 3), while in the Bellaveduta, Calvino and Arcieri wells, located along the fault scarp, Messinian evaporites are present at the top of the Apulian 


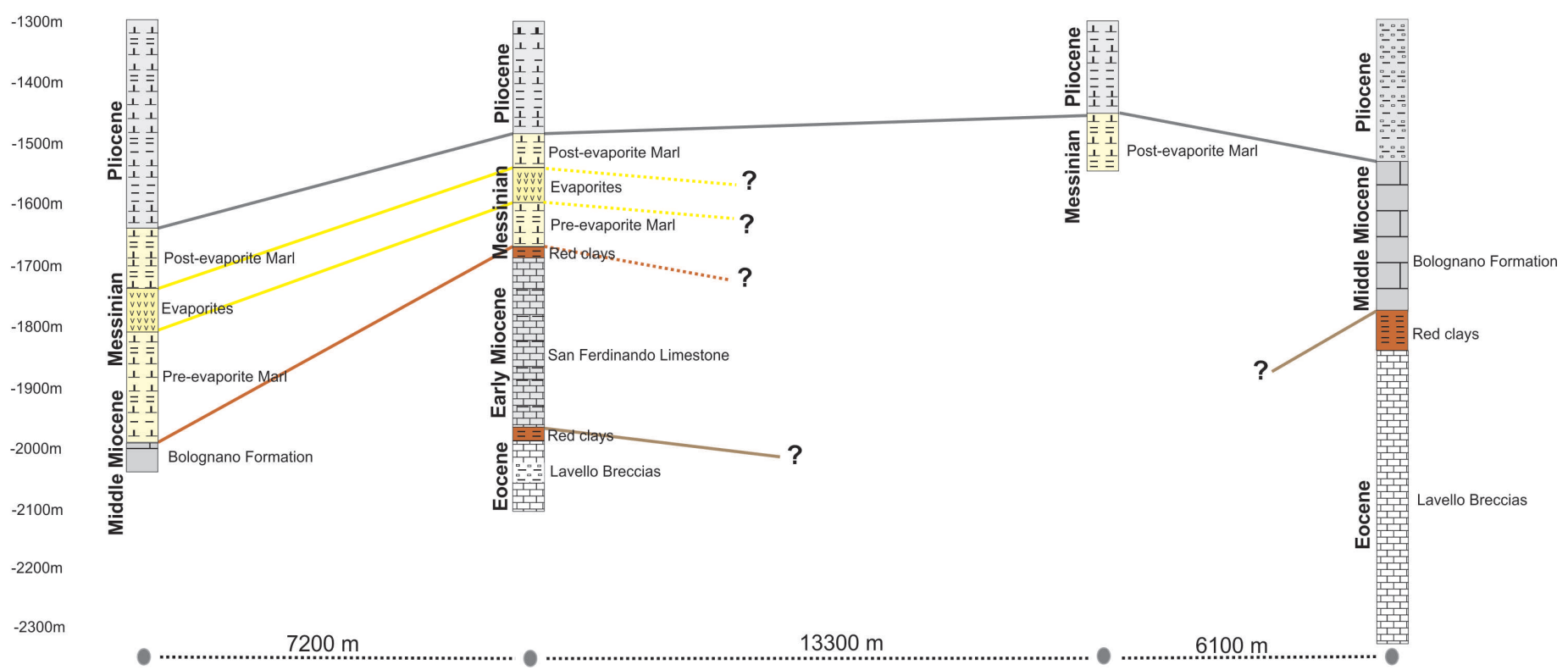

Fig. 7 - Schematic stratigraphic profile, parallel to the fault scarp, derived from the correlation of Bellaveduta1, Calvino1, Arcieri1 and Musacchio1 exploration wells. See Figure 3 for the location of the wells.

platform (Fig. 7). The Bellaveduta well shows the maximum thickness of Messinian deposits, which are up to $350 \mathrm{~m}$-thick and include pre-evaporitic, evaporitic and post-evaporitic intervals. The former one, about 173 m-thick, consists of alternating packstones and wackstones (sensu Dunham, 1962). The evaporitic interval is made up of $84 \mathrm{~m}$-thick gray marls, intraclastic packstones, crystalline anhydrites and blackish coals, whereas, the post-evaporitic one is $93 \mathrm{~m}$-thick and includes gray marls and intraclastic packstones (sensu Dunham, 1962). At the Calvino well, the Messinian deposit is made up of $105 \mathrm{~m}$-thick pre-evaporitic marls, $35 \mathrm{~m}$-thick evaporitic gypsum, and $60 \mathrm{~m}$-thick post-evaporitic marls. At the Arcieri well, only the post-evaporitic interval is present. There, we recognize an about $56 \mathrm{~m}$-thick interval topping volcanic rocks of Eocene age. Indeed, the Eocene interval, which includes pyroclastic rocks (RicchetTi et alii, 1988), is up to about 1000 m-thick (Fig. 6b), and it shows marked lateral variations of thickness with the thickest portion localized in the Matinella1 area (\#18 of Fig. 6b).

\section{TIMING AND KINEMATICS OF FAULTING}

As shown in figure 8, the easternmost, NW-SE oriented, pronounced scarp displaces the Eocene-Upper Miocene units. For this reason, the NW-SE feature is interpreted as an extensional fault zone down-dropping southwestward the Apulian Platform. In detail, the westernmost fault segment (fault A in Fig. 8) bounds eastward the wedge-shaped, laterally discontinuous Messinian deposit (pre- to post-evaporitic facies), which thickens towards the high-angle faults (i.e., Fault A). A syn-sedimentary, Messinian fault activity is therefore inferred. The individual NW-SE fault segments are topped by Early
Pliocene units, which are mainly made up of calcareous clays and quartz-rich sandstones (Bellaveduta well, \#4 in Fig. 3) that commonly postdate faulting. Along the seismic profile, the Middle Pliocene-Pleistocene basin infill shows onlap geometries against the carbonate bedrock. Only in one case, a NW-SE trending fault segment crosscuts the lowermost portion of the Early Pliocene deposits, suggesting an Upper Miocene-Early Pliocene timing of faulting. Regarding the kinematics of the NW-SE striking faults, data reported in figure 8 are consistent with predominant extensional faulting. However, taking into account that the Messinian interval shows a greater thickness in correspondence of the Bellaveduta well (Fig. 7), which localizes in between two right-stepping, adjacent NW-SE fault segments, a minor right-lateral slip component during pre-to syn-Messinian time is also inferred for the NW-SE fault zones.

Figure 9 reports an interpreted NW-SE oriented seismic profile in which the N-S striking faults, which abut against the main NW-trending faults (Fig. 11c), are characterized by a pronounced listric geometry and displace the gently folded Eocene-Miocene succession (i.e., x's in Fig. 9b). The Early Pliocene deposits cover the N-S faults, post-dating them; however, the southeastern fault segment shown in the aforementioned figure displaces the bottom Early Pliocene surface.

Figure 10 shows that the NNE-SSW morphological lineaments correspond to fault scarps crosscutting the Eocene-to-Early Pliocene succession. These faults likely affected the Pliocene sedimentary depocenters, exhibiting an extensional component of slip. Furthermore, the seismic profile of figure 10 also shows that a growth fold characterized by an apparent wave-length of about $9 \mathrm{~km}$ formed during Miocene times as suggested by the significant thickness variation of the Miocene deposit. In fact, the 

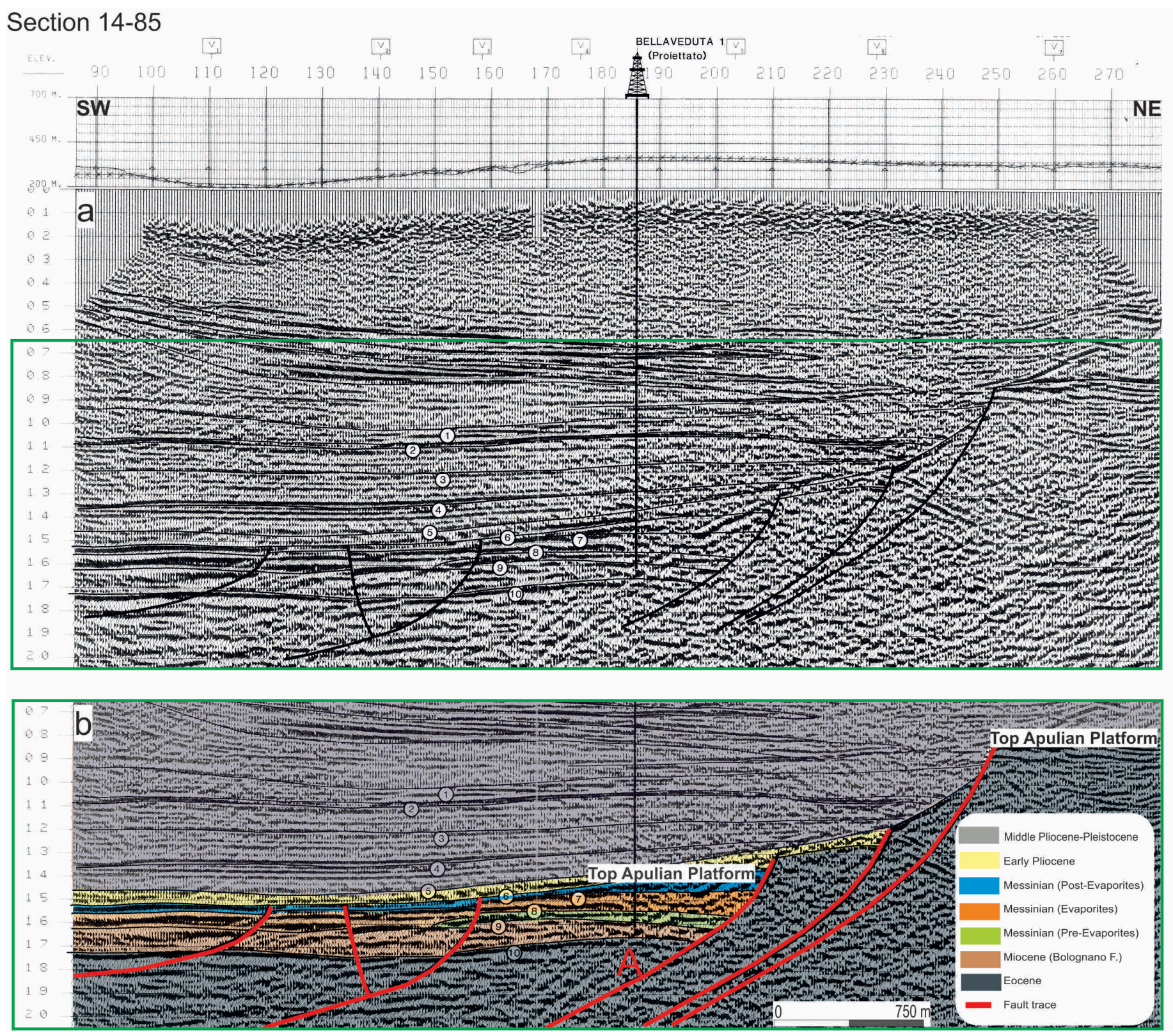

Fig. 8 - a) Uninterpreted and (b) interpreted NE-SW oriented seismic reflection profiles 14-85, showing listric NW-SE faults geometry and syn-sedimentary activity of Messinian deposits (1-conglomerates, 2-top sands of Bellaveduta well, 3-bottom sands of Bellaveduta well, 4-calcarenitic level, 5-top Early Pliocene, 6-top carbonates, 7-gypsum, 8-top lacustrine, 9-top limestone and dolomite, 10-top Cretaceous).

evaporites are characterized by a thickness variation from 76 to 230 meters, and the San Ferdinando limestone from 174 to $240 \mathrm{~m}$.

The digitalization of the isochron maps of the Acerenza, Ripacandida and Venosa Permissions (VIDEPI ProJEcT), which actually report faults displacing the generic Top Apula surface (Fig. 11a), permits to decipher the abutting and crosscutting relationships about all fault sets in the study area. In fact, we note that some of the NE-SW fault traces terminate against the NW-SE ones (cf., Gaudiano area, Fig. 11b). This structural configuration is consistent with the NE-SW faults postdating the NW-SE structures, forming cross-orthogonal extensional features that dissected the horst bounded by the latter high-angle faults.

\section{DISCUSSION}

In this section, we first discuss the results of 3D geological modeling to assess both time and kinematics of the main fault zone that crosscuts the Apulian carbonates. Then, the minor faults are taken into account to decipher their possible interaction with the aforementioned structural feature. Finally, both timing and kinematics of faulting are discussed in light of the existing bibliography to provide new insights on the Tertiary to Quaternary tectonic evolution of the northern portion of the Apulian Platform, at the boundary with the Adria plate.

The gradual, SW-directed deepening of the Apulian Platform (DE Dominicis \& Mazzoldi, 1987; Sella et alii, 1988; De Alteriss \& Aiello, 1995) is characterized by two prominent fault scarps. The eastward one is due to NW- 

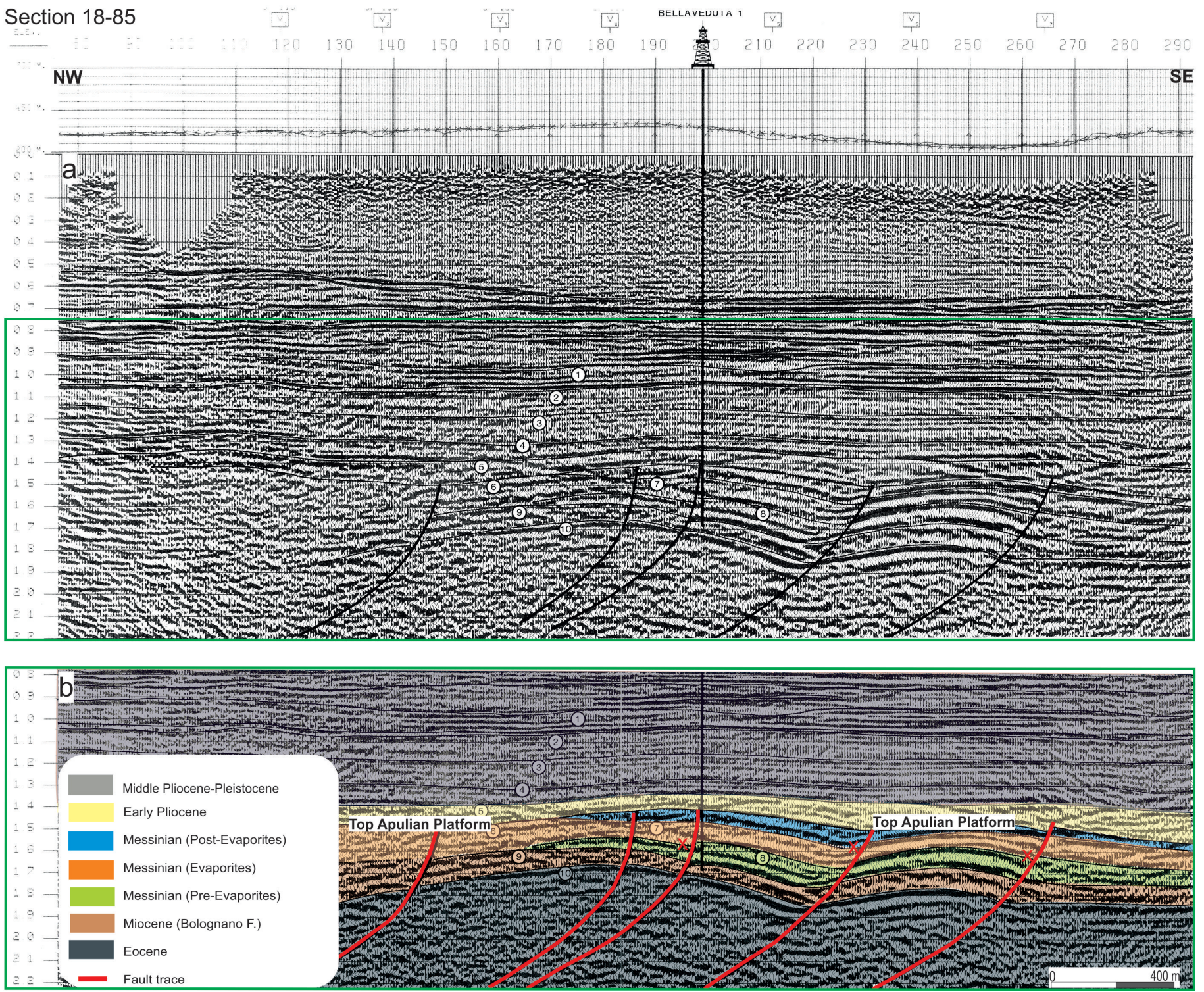

Fig. 9 - (a) Uninterpreted and (b) interpreted NW-SE oriented seismic reflection profiles 18-85 across the north-western sector of the study area, showing the listric geometry of the N-S directed fault zone that displaces gently-folded Eocene-Miocene succession (4-calcarenitic level, 5-top Early Pliocene, 6-top carbonates, 7- gypsum, 8-top lacustrine, 9-top limestone and dolomite, 10-top Cretaceous). See Figure 3 for location.

SE to NNW-SSE trending faults which display dominant dip-slip, extensional kinematics, and a subordinate strikeslip component. By considering the location of the Messinian deposits, present only at the hanging wall of the most prominent fault scarp, and the thicker Early Pliocene deposits found at the same location (Fig. 7),we interpret the aforementioned structures as extensional faults Messinian - Early Pliocene in age. Similar kinematics were also proposed for the NW-SE faults that crosscut the Apulian carbonates of southern Italy by RicchetTI et alii (1988), LUPERTo Sinni \& Borgomano (1989), Pieri \& LaViano (1989), Mindszenty et alii (1995), IANNONE (1996), Festa et alii (2003), Patacca \& Scandone (2004), Spalluto (2012), SantANTONIO et alii (2012), and LA Bruna et alii (2017). However, a close view at the lateral variation of the Messinian deposits, which form thicker successions at the Bellaveduta site (Fig. 7) suggests that the NW-SE faults were likely affected by transtensional kinematics. There, the NNW-SSE trending extensional faults bound a small, pull-apart basin localized at a releasing jog of the aforementioned fault segments. In the southern Adriatic Basin, the NNW-SSE faults were also interpreted as extensional features by MoRELLI (2002). Differently, in the Murge Plateau, left-lateral, strike-slip kinematics were proposed for sub-parallel faults by KoRnEva et alii (2014), PANZA et alii (2015, 2016), and ZAMBRANo et alii (2015).

The structural network present in the Apulian Platform might be also due to an older deformation. KorNEvA et alii (2014) assigned an Upper Cretaceous age to the fault system made up of WNW-ESE, NNW-SSE, and NW-SE faults characterized by right-lateral, left-lateral, and extensional kinematics, respectively, which crop out in the Murge Plateau. The latter features likely re-activated older strike-slip faults. Regarding the fault kinematics, an extensional activity was also proposed by for the NW-SE faults that crop out in different area of southern Italy. Similarly, 

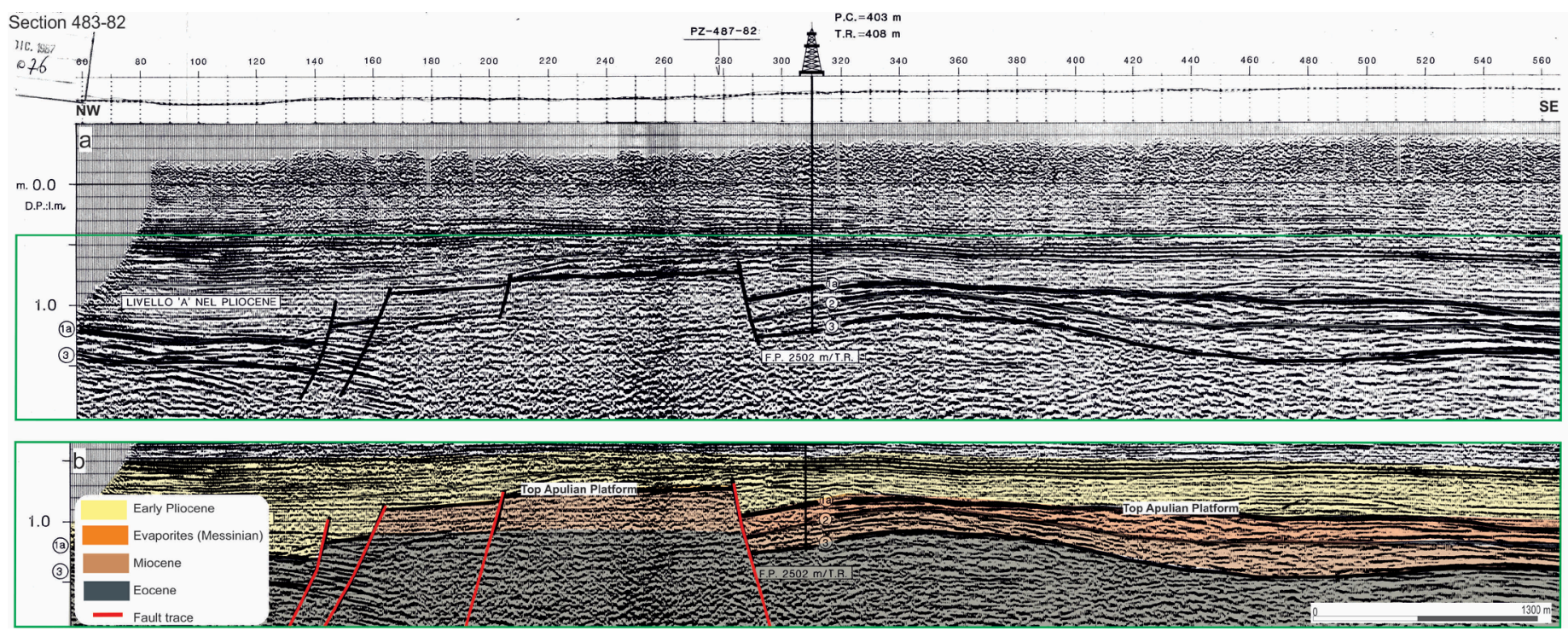

Fig. 10 - (a) Uninterpreted and (b) interpreted NW-SE oriented seismic reflection profiles 483-82 showing NNE-SSW fault scarps that crosscut the Eocene-to-Early Pliocene succession (1a-Bottom Pliocene, 2-Top Miocene San Ferdinando limestone, 3-Top Eocene Lavello breccias). See Figure 3 for location.

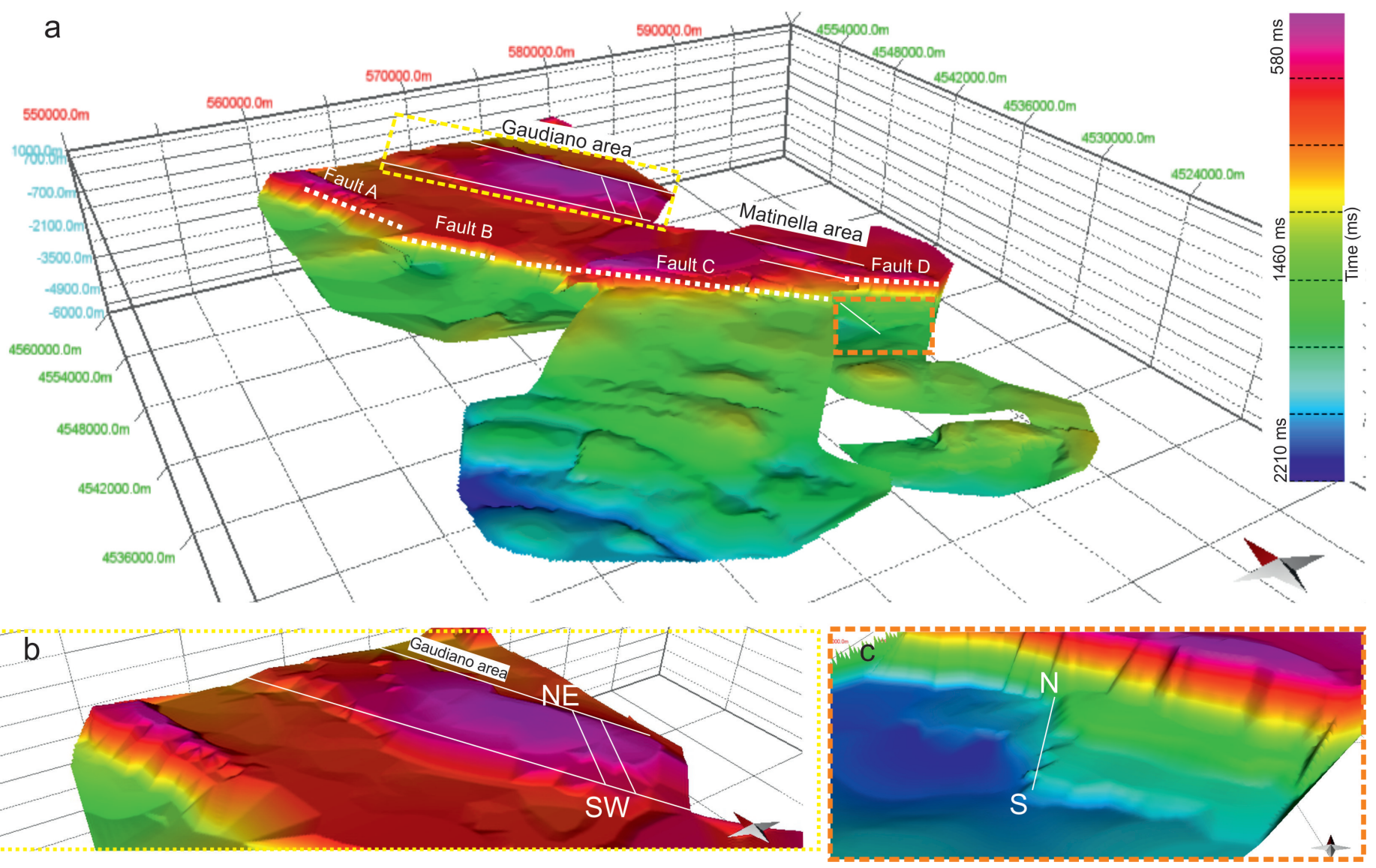

Fig. 11 - (a) Digitalization of the isochron maps and the fault traces of the Acerenza, Ripacandida and Venosa Permissions (ViDEPI Project) with the fault scarps traces interpreted by taking into account the displacement of the generic top Apula surface; (b) the NE-SW fault terminate against the NW-SE ones (cf., Gaudiano area); (c) N-S fault cuts a NW-SE fault. The legend bar on the right shows with different colors the Apulian Platform surface in time (ms).

in the same area, LAURITA et alii (2016) also documented presence of syn-sedimentary, Upper Cretaceous in age, $\mathrm{N} 120^{\circ}$ extensional fissures infilled with a calcareous breccias embedded in a reddish, kaolinite-bearing calcite ma- trix with oxides, hematite and bauxite fragment. Moreover, a Plio-Pleistocene age has been attributed to the NNW-SSE extensional faults exposed in the Murge Plateau by PIERI et alii (1997) and Tropeano et alii (1997). We observe that 

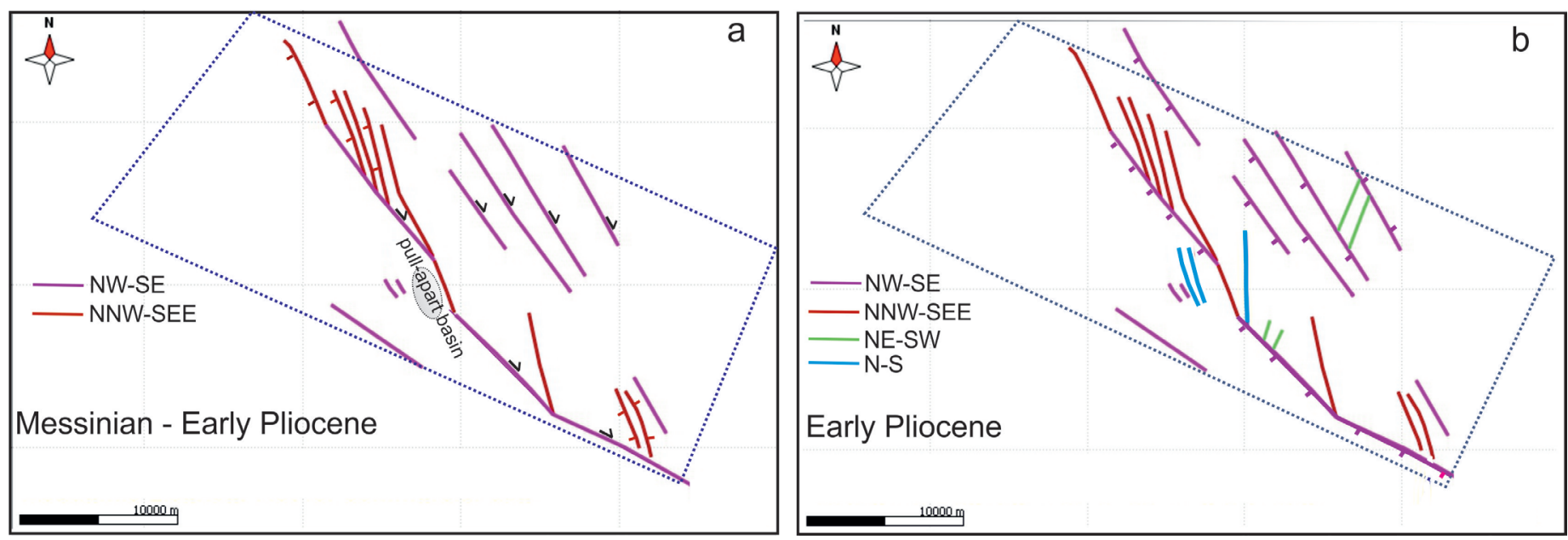

Fig. 12 - Structural model for the Messinian - Early Pliocene (a) and the Early Pliocene (b) evolution of the study area.

both kinematics are compatible with the model proposed by KoRnEva et alii (2014). The latter authors recognized a mechanism of fault growth similar to that inferred for the strike-slip fault system of the Valley of Fire, Nevada (USA), which developed thanks to the extensional brittle structures that formed at the extensional quadrants localized at the mode-II tips of pre-existing sheared heterogeneities (MYers \& Aydin, 2004; Flodin \& Aydin, 2004). In carbonate rocks, although the invoked deformation mechanisms are not similar, a similar structural configuration was documented in the Pleistocene grainstones cropping out at the Favignana Island (Tondi et alii, 2012), and in the ramp Apulian carbonates exposed in the Majella Mt. (ANTONELLINI et alii, 2008).

Taking into account the other minor fault sets, the N-S and NE-SW fault sets cropping out in the Murge Plateau were interpreted as dip-slip extensional faults of Pliocene-Quaternary age by CiARANFi et alii (1988), Pieri et alii (1997), and KorNeva et alii (2014). Based upon the data reported in this article, we confirm such a hypothesis due to their abutting relationships with respect to the NW-SE fault zone. In fact, both fault sets terminate against the latter structural feature, suggesting a most recent faulting activity relative to the major fault zone. Furthermore, at the hanging wall of this large-scale structural feature, a N-S fault crosscut an isolated NW-SE fault, supporting therefore our interpretation (Fig. 11c). Finally, an Early Pliocene age is inferred for the NNE-SSW fault that bounds a coeval depocenter located on top of the growth anticline that involved Miocene deposits (Fig. 10b). Presence of a NNE- to NE-trending fault set in the Gargano Promontory was previously reported only by BILLI et alii (2007), who attributed right-lateral strike-slip kinematics. In light of this data, we infer a possible Messinian-to-Early Pliocene, oblique-slip extensional activity to the NNE-SSW faults, which likely formed at the hanging wall of the extensional NW-SE faults as already documented in the Bolognano (Miocene) and Cima delle Murelle (Cretaceous) Fms. exposed in the Majella Mt. (Agosta et alii, 2009; Aydin et alii, 2010).Considering the aforementioned growth-fold, ca. NW-SE oriented fold axes were documented in the carbonate succession, including the Late Pliocene deposits, of the Gargano Promontory by BеRтотті et alii (1999), who interpreted them as second-order structures associated to the left-lateral slip that occurred along the Mattinata Fault. Sub-parallel folds were also documented in the carbonates of the Murge Plateau (Felici, 2008).

In light of the aforementioned discussion, we interpret both folding of the Cenozoic rocks and right-lateral, transtensional kinematics of the NW-SE faults as an Upper Miocene deformation likely associated to collision and thrusting of the Dinarides-Hellenides mountain belt (AuBouin et al., 1970). Such a deformation, which therefore pre-dates that commonly associated to the evolution of the Apennine fold-and-thrust belt, corresponds to the effects of thrusting in the Dinarides-Hellenides mountain belt recognized in the Gargano Promontory (BеRTOTTI et alii 2009; 2001; CASOlari et alii 2000; BranKMAN \& Aydin, 2004; Billi et alii 2007). Moreover, our interpretation agrees with the previous work of Mostardini \& MERLINi (1986) and CASERo et alii (1992), and may shed a new light on the complex structural evolution of the high-angle fault network that dissects the outer Apulian Platform.

\section{CONCLUSIONS}

In this work, the activity of the main fault segments affecting the foreland-foredeep domains of a portion the Southern Apennines is investigated on the basis of the thickness distribution of Cenozoic deposits and in light of its structural architecture. The study area lies in between the Vulture Volcano and the Murge Plateau, southern Italy, where voluminous, Eocene-Miocene in age, mixed clastic-carbonate sequences are topped by the Pliocene-Pleistocene sediments of the Bradano Trough. Both thickness and lithological variations of the Miocene and Eocene successions were assessed by mean of well log analysis, seismic reflection profile interpretation, and 3D geological modeling.

The major NW-SE fault scarp, which bounds eastward a tectonic depression infilled with Pliocene-Pleistocene deposits, is comprised of high-angle faults that juxtapose stratigraphic units of different age. Messinian - Early Pliocene in age, transtensional, right-lateral kinematics are inferred for the NW-SE fault segments, which produced extensional deformation with formation of small, pullapart basins located at the releasing jogs. There, NNW-SSE 
trending, extensional splay faults bounded the aforementioned basins (Fig. 12a). From the Early Pliocene until the Late Pleistocene, the whole study area was affected by extensional tectonics, with formation of minor N-S, NE-SW and NNE-SSW fault sets. A dip-slip extensional activity is inferred for the three fault sets (Fig. 12b).

The study area shows the product of a series of geodynamic events that took place in the Mediterranean region. In fact, it was tectonically influenced by two non-coeval orogenic systems, the SW-vergent Dinaride and the NE-vergent Apennine belts, respectively. During convergence movements between Africa and Eurasian plates, the Adria/Apulia continental block played a crucial role in the closure of the Mesozoic Alpine Tethys Ocean. So, the timing of deformation of the study area can be due to the deformation transmitted from the adjacent Dinarides (Eocene-Oligocene) and Apennines (Pliocene) growing chains. However, the faults present in the study area may also be due to shearing localized along pre-existing faults, which therefore shows a multiphase activity that produced very scalloped fault scarps.

\section{ACKNOWLEDGEMENTS}

The present work was supported by CNR-IMAA, through the MISE-ITALY Atlante Project, and the Reservoir Characterization Project. We acknowledge the revisions provided by Sabina Bigi, Andrea Billi and anonymous referee, and comments and suggestions of the associate editor. We also thank Lucia Pippa for her help in log analysis and Fabrizio Felici for his the revision of a first draft of the manuscript. Midland Valley is greatly acknowledged for letting us the opportunity to use the Move ${ }^{\mathrm{TM}}$ software by providing the required academic licenses. The present work is part of the first author's PhD Thesis Dissertation.

\section{REFERENCES}

Agosta F. (2008) - Fluid flow properties of large, basin-bounding normal fault zones in massive carbonates. In: Wibberley, C., Kurz, W. Imber, J., Holdsworth, R., Collettini, C.. The Internal Structure of Fault Zones: Implications for Mechanical and Fluid-Flow Properties, 299, 277-291.

Agosta F., Mulch A., Chamberlain P. \& Aydin A. (2008) - Geochemical traces of CO2-rich fluid flow along normal faults in central Italy. Geophysical Journal International, 174, 758-770.

Agosta F., Alessandroni M., Tondi E. \& Aydin A. (2009) - Oblique normal faulting along the northern edge of the Majella anticline, central Italy: inferences on structurally controlled hydrocarbon flow. Journal of Structural Geology, 31, 674-690.

Anderson H.A. \& Jackson J.A. (1987a) - Active tectonics of the Adriatic region. Geophys Journ. R. Astron. Soc., 91, 937-983.

Argnani A., Favali P., Frugoni F., Gasperini M., Ligi M., Marani M., Mattietti G. \& Mele

G. (1993) - Foreland deformational pattern in the Southern Adriatic Sea. Ann. Geofis. 36, 229-247.

Argnani A., Rovere M. \& Bonazzi C. (2009) - Tectonics of the Mattinata fault, offshore south Gargano (southern Adriatic Sea, Italy): Implications for active deformation and seismotectonics in the foreland of the Southern Apennines. Geological Society of America Bulletin, 121, 1421-1440.

Aubouin J., Blanchet R., Cadet J. P., Celet P., Charvet J., Chorowicz J. \& Rampnoux J. P. (1970) - Essai sur la géologie des Dinarides. Bulletin de la Société géologique de France, 6, 1060-1095.

Aydin A., Antonellini M., Tondi E. \& Agosta F. (2010) - Deformation along the leading edge of the Majella thrust sheet in central Italy. Journal of Structural Geology, 32, 1291-1304.

Antonellini M., Tondi E., Agosta F., Aydin A. \& Cello G. (2008) - Failure modes in deep-water carbonates and their impact for fault development: Majella Mountain, Central Apennines, Italy. Marine and Petroleum Geology, 25, 1074-1096.
Azzaroli A. (1968) - Calcarenite di Gravina. Studi illustrativi della Carta Geologica d'Italia - Formazioni Geologiche. Servizio Geologico d'Italia, I, 183- 185.

Balduzzi A., Casnedi R., Crescenti U. \& Tonna M. (1982b) - Il Plio-Pleistocene del sottosuolo del bacino lucano (Avanfossa Appenninica). Geol. Rom., 21, 89-111.

Bertotti G., Casolari E. \& Picotti V. (1999) - The Gargano Promontory: a Neogene contractional belt within the Adriatic plate. Terra Nova, 11, 168-173.

Bertotti G., Picotti V., Chilovi C., Fantoni R., Merlini S. \& Mosconi A. (2001) - Neogene to Quaternary sedimentary basins in the south Adriatic (central Mediterranean): Foredeeps and lithospheric buckling. Tectonics, 20, 771-787,

Billi A., Gambini R., Nicolai C. \& Storti F. (2007) - Neogene-Quaternary intraforeland transpression along a Mesozoic platform-basin margin: The Gargano fault system, Adria, Italy. Geosphere, 3, 1-15.

Billi A. \& SALVINI F. (2000) - Sistemi di fratture associati a faglie in rocce carbonatiche: nuovi dati sull'evoluzione tettonica del Promontorio del Gargano. Boll. Soc. Geol. It., 119, 237-250.

Bosellini A., Morsilli M. \& NerI C. (1999) - Long-term event stratigraphy of the Apulia platform margin (Upper Jurassic to Eocene, Gargano, Southern Italy). J. Sedim. Res., 69, 1241-1252.

Brankman C. \& Aydin A. (2004) - Uplift and contractional deformation along a segmented strike-slip fault system: The Gargano Promontory, southern Italy. Journal of Structural Geology, 26, 807-824.

Casero P., Roure F., Endignoux L., Moretti I., Muller C., Sage L. \& VialLY R. (1992) - Neogene geodynamic evolution of the Southern Apennines. Mem. Soc. Geol. Ital., 41, 109-120.

Casero P., Roure F., Moretti I., Muller C., Sage L. \& Vially R. (1988) Evoluzione geodinamica neogenica dell'Appennino Meridionale. In L'Appennino Campano-Lucano nel quadro geologico dell'Italia Me ridionale. Atti del $74^{\circ}$ Congresso Soc. Geol. It., relazioni, 59-66.

CASNEDI R. (1988a) - La Fossa Bradanica: origine, sedimentazione e migrazione. Mem. Soc. Geol. It., 41, 439-488.

Casolari E., Negri A., Picotti V. \& Bertotti G. (2000) - Neogene stratigraphy and sedimentology of the Gargano Promontory (southern Italy). Eclogae geol. Helv., 93, 7-23.

Cello G., Tortorici L., Martini N. \& Paltrinieri W. (1989) - Structural styles in the frontal zones of the southern Apennines, Italy: an example from the Molise district. Tectonics, 8, 753-768.

Cello G., Lentini F. \& Tortorici L. (1990) - La struttura del settore calabro-lucano e suo significato nel quadro dell'evoluzione tettonica del sistema a thrust sudappenninico. Studi Geol. Camerti, 27-34.

Channel J., D'Argenio B. \& Horvath F. (1979) - Adria, the African promontory in Mesozoic Mediterranean paleogeography. Earth Science Review, 15, 213-292.

Chilovi C., De Feyter A.J. \& Pompucci A. (2000) - Wrench zone reactivation in the Adriatic Block: the example of the Mattinata Fault System (SE Italy). Boll. Soc. Geol. It., 119, 3-8.

Ciaranfi N., Guida M., Iaccarino G., Pescatore T., Pieri P., Rapisardi L. \& TuRco E. (1983) - Elementi sismotettonici dell'Appennino meridionale. Boll. Soc. Geol. It., 102, 201-222.

Ciaranfi N., Pieri P. \& Ricchetti G. (1988) - Note alla carta geologica delle Murge e del Salento (Puglia Centromeridionale). Mem. Soc. Geol. It., 41, 449-460.

Colantoni P., Tramontana M. \& Tedeschi R. (1990) - Contributo alla conoscenza dell'avampaese apulo: struttura del Golfo di Manfredonia (Adriatico meridionale). Giornale di Geologia, 52, 19-32.

CREscenti U. (1969) - Stratigrafia della serie calcarea dal Lias al Miocene nella regione marchigiano - abruzzese. Mem. Soc. Geol. It., 8, 343-420.

D'Argenio B., Pescatore T. \& Scandone P. (1973) - Schema geologico dell'Appennino Meridionale (Campania e Lucania). Accademia Nazionale dei Lincei, 182, 49-72.

De AlteriIs G. \& Aiello G. (1993) - Stratigraphy and tectonics offshore of Puglia (Italy, southern Adriatic Sea). Marine Geology, 113, 233253.

De AlteriIs G. (1995) - Different foreland basins in Italy: examples from the central and southern Adriatic Sea. Tectonophysics, 252, 349373.

Dercourt J., Zonenshain L.P., Ricou L.E., Le Pichon X., Knipper A.L., Grandjaquet C., Sbortshikov I.M., Geussant J., Lepvrier C., Pechersku D.H., Boulin J., Bazhenov M.L., Lauer J.P. \& Biju- 
Duval, B. (1986) - Geological evolution of the Tethys belt from the Atlantic to the Pamirs since the Lias. Tectonophysics, 123, 241-315

De Dominicis A. \& Mazzoldi G. (1987) - Interpretazione geologico strutturale del margine orientale della piattaforma Apula. Mem. Soc. Geol. It., 38, 163-176.

Del Gaudio V., Pierri P., Frepoli A., Calcagnile G., Venisti N. \& Cimini G.B. (2007) - A critical revision of the seismicity of Northern Apulia (Adriatic microplate - Southern Italy) and implications for the identification of seismogenic structures. Tectonophysics, 436, 9-35.

Dewey J.F., Helman M.L., Turco E., Hutton D.H.W. \& Knott S.D. (1989) - Kinematics of the western Mediterranean. M.P. Coward D. Dietrich, R.G. Park (Eds.), Geol. Soc. London, Spec. Publ., 45 265-283.

DimitriJević M.D. (1997) - Geology of Yugoslavia. Geological Institute GEMINI, Belgrade, p. 187.

Doglioni, C., Tropeano, M., Mongelli, F. \& Pieri P. (1996) - Middle-Late Pleistocene uplift of Puglia: An "anomaly" in the Apenninic foreland. Mem. Soc. Geol. It., 51, 101-117.

Favali P., Funiciello R., Mattietti G., Mele G. \& Salvini F. (1993) - An active margin across the Adriatic Sea (central Mediterranean Sea). Tectonophysics, 219, 109-117.

DunHAM R.J. (1962) - Classification of carbonate rocks according to depositional texture in HAM, w. e. (ed), Classification of carbonate rocks. A. A. P. G. Memoir, 1, 108-121.

Favali P., Mele G. \& Mattietti G. (1990) - Contribution to the study of the Apulian microplate geodynamics. Mem. Soc. Geol. It., 44, 71-80.

FELICI F. (2008) - Tectonics of the Adria/Apulia Plate boundary during the Cretaceous-Miocene time. Ph.D. Thesis, 2008.

FESTA V. (2003) - Cretaceous structural features of the Murge area (Apulian Foreland, southern Italy). Eclogae Geologicae Helvetiae, 96, 11-22.

FINETTI I. (1984) - Struttura ed evoluzione della microplacca Adriatica (Structure and evolution of the Adriatic microplate). Bollettino di Oceanografia Teorica e Applicata, II, 115-123.

Flodin E. \& Aydin A. (2004) - Faults with asymmetric damage zones in sandstone, Valley of Fire State Park, southern Nevada. Journal of Structural Geology, 26, 983-988.

Funiciello R., Montone P., Salvini F. \& Tozzi M. (1988) - Caratteri strutturali del Promontorio del Gargano. Mem. Soc. Geol. It., 41, 1235 1243.

Funiciello R., Montone P., Parotto M., Salvini F. \& Tozzi M. (1991) Geodynamical interpretation of an intra-orogenic foreland: the Apulia case history (Italy). Boll. Soc. Geol. It., 110, 419-425.

Gambini R. \& Tozzi M. (1996) - Tertiary geodynamic evolution of the Southern Adria microplate. Terra Nova, 8, 593-602.

GuERRICCHIO A. (1983) - Strutture tettoniche di compressione nel Gargano di elevato interesse applicativo evidenziate da immagine da satellite. Geologia Applicata e Idrogeologia, 18, 491-505.

IAnnone A. \& Pieri P. (1982). Caratteri neotettonici delle Murge. Geol. Appl. e Idrogeol., XVII, 147-159.

IANNONE A. (1996) - Segnalazione di strutture da deformazione sinsedimentaria in una successione carbonatica cenomaniana, nei pressi di Bari. Mem. Soc. Geol. Ital. 51, 209-215.

Korneva I., Tondi E., Agosta F., Rustichelli A., Spina V., Bitonte R. \& Di CUIA R. (2014) - Structural properties of fractured and faulted Cretaceous platform carbonates, Murge Plateau (southern Italy). Marine and Petroleum Geology, 57, 312-326.

La Bruna V., Agosta F. \& Prosser G. (2017) - New insights on the structural setting of the Monte Alpi area, Basilicata, Italy. Italian Journal of Geosciences, 10.3301/IJG.2017.03.

Laurita S., Agosta F., Cavalcante F., Rustichelli A. \& Giorgioni M. (2016) - Shearing of syn-sedimentary carbonate breccia along strike-slip faults, Altamura Fm., Southern Italy. Ital. J. of Geosc. Special Issue on "Fractured carbonate reservoirs and fluid flow", 135, 41-54.

Luperto Sinni E. \& Borgomano J. (1989) - Le Crétacé supérieur des Murges sudorientales (Italie Méridionale): stratigraphie et évolution des paléoenvironnements. Riv. Ital. Paleont. Strat. 95, 95-136.

Malinverno A. \& Ryan W.B.F. (1986) - Extension in the Tyrrhenian Sea and shortening in the Apennines as a result of arc migration driven by sinking of the lithosphere. Tectonics, 5, 227-245.

Mariotti G. \& Doglioni C. (2000) - The dip of the foreland monocline in the Alps and Apennines. Earth Planet. Sc. Lett., 181, 191-202.
Migliorini C. (1944) - Elementi basaltici in una breccia calcarea luteziana nel sottosuolo di Genzano di Lucania. Boll. Soc. Geol. It. 62, 50-51.

Monti F., Bronzetti F. \& Lavecchia G. (2005) - Structural and kinematic analysis of the Mattinata fault zone (Gargano, southern Italy) Implications for the active deformation field. Convegno Gruppo Nazionale Geofisica della Terra Solida. Abstract book, 24, 36-37.

Morelli D. (2002) - Evoluzione tettonico-stratigrafica del margine Adriatico compreso tra il promontorio garganico e Brindisi. Mem. Soc. Geol. It., 57, 343-353.

Mostardini F. \& Merlini S. (1986) - Appennino centro meridionale. Sezioni geologiche e proposta di modello strutturale. Mem. Soc. Geol. It., 35, 177-202.

MYERS R. \& AYDIN A. (2004) - The evolution of faults formed by shearing across joint zones in sandstone. Journal f Structural Geology, 26, 947-966.

Mindszenty A., D’Argenio B. \& Aiello G. (1995) - Lithospheric bulges recorded by regional unconformities. The case of Mesozoic-tertiary Apulia. Tectonophysics, 252, 137-161.

Nicolai C. \& GAMBInI R. (2007) - Structural architecture of the Adria platform-and-basin system. Italian Journal of Geosciences, 7, 21-37.

Ortolani F. \& Pagliuca S. (1987) - Tettonica transpressiva nel Gargano e rapporti con le catene Appenninica e Dinarica. Mem. Soc. Geol. It., 38, 205-224.

Pamic J., Gui I., Jelaska V. (1998) - Geodynamic evolution of the Central Dinarides. Tectonophysics, 297, 251-268.

Panza E., Agosta F., Zambrano M., Tondi E., Prosser G., Giorgioni M. \& JANISECK J. M. (2015) - Structural architecture and Discrete Fracture Network modelling of layered fractured carbonates (Altamura Fm. Italy). Italian Journal of Geosciences, 134, 409-422.

Panza E., Agosta F., Rustichelli A., Zambrano M., Tondi E., Prosser G., GIORgIONI M. \& JANISECK, J.M. (2016) - Fracture stratigraphy of shallow-water, layered limestone rocks: inferences on the fluid flow properties of fractured tight carbonate reservoirs. Marine and Petroleum Geology, 73, 350-370.

Patacca E., Sartori P. \& Scandone P. (1990) - Tyrrhenian basin and apenninic arcs: kinematic relations since late tortonian times. Mem. Soc. Geol. It., 45, 425-451.

Patacca E. \& Scandone P. (2001) - Late thrust propagation and sedimentary response in the thrust belt-foredeep system of the Southern Apennines (Plio-Pleistocene). In Vai G.B. \& Martini P. ed., Anatomy of a Mountain: the Apennines and adjacent Mediterranean Basin. Kluver Acad. Publ., 401-440.

Patacca E. \& Scandone P. (2004) - The 1627 Gargano earthquake (southern Italy): Identification and characterization of the causative fault. Journal of Seismology, 8, 259-273.

Patacca E. \& Scandone P. (2007) - Geology of the Southern Apennines Boll. Soc. Geol. It., Spec. Issue No. 7, 75-119, CROP-04 (ed. by A. Mazzotti, E. Patacca and P. Scandone).

Peacock D. P., Fisher Q. J., Willemse E. M. \& Aydin A. (1998) - The relationship between faults and pressure solution seams in carbonate rocks and the implications for fluid flow. Geological Society, London, Special Publications, 47, 105-115

Pescatore T. (1978) - Evoluzione tettonica del Bacino Irpino (Italia meridionale) durante il Miocene. Boll. Soc. Geol. Ital., 97, 783-805.

PicCARDi L. (1998) - Cinematica attuale, comportamento sismico e sismologia storica della faglia attiva di Monte Sant'Angelo (Gargano): la possibile rottura superficiale del leggendario terremoto del 493 d.C. Geografia Fisica e Dinamica Quaternaria, 21, 155-166.

Pieri P. \& LaVIano A. (1989) - Tettonica e sedimentazione nei depositi senoniani delle Murge sud-orientali (Ostuni). Boll. Soc. Geol. It. 108, 351-356.

Pieri P., Festa V., Moretti M. \& Tropeano M. (1997) - Ouaternary tectonic activity of the Murge area (Apulian foreland-Southern Italy). Annali di geofisica, v. XL, n. 5.

Ricchetti G., Ciaranfi N., Luperto Sinni E., Mongelli F. \& Pieri P. (1988) - Geodinamica ed evoluzione sedimentaria e tettonica dell'avampaese apulo. Mem. Soc. Geol. It., 41, 57-82.

Roveri M., Bassetti M. A. \& Ricci Lucchi F. (2001) - The Mediterranean Messinian salinity crisis: an Apennine foredeep perspective. Sedimentary Geology, 140, 201-214.

SAlvini F., Billi A. \& Wise D.U. (1999) - Strike-slip fault-propagation cleavage in carbonate rocks: the Mattinata Fault Zone, Southern Apennines, Italy. J. of Struct. Geol., 21, 1731-1749. 
Santantonio M., Scrocca D \& Lipparini L. (2012) - The Ombrina-Rospo Plateau (Apulian Platform): evolution of a carbonate platform and its margins during the Jurassic and Cretaceous. Mar. Pet. Geol., $1-26$.

Scandone P. (1972) - Studi di geologia lucana: carta dei terreni della serie calcareo-silico-marnosa e note illustrative. Boll. Soc. Natur. Napoli, 81, 225-300.

Schettino A. \& Turco E. (2011) - Tectonic history of the western Tethys since the late Triassic. Geological Society of America Bulletin, 123, 89-105.

ScISCIANI V. \& CALAMITA F. (2009) - Active intraplate deformation within Adria: Examples from the Adriatic region. Tectonophysics $\mathbf{4 7 6}$ 57-72.

Sella M., Turci C. \& Riva A. (1988) - Sintesi geopetrolifera della Fossa Bradanica (Avanfossa della catena Appenninica). Mem. Soc. Geol. It., 41, 87-107.

SPALLuto L. (2012) - Facies evolution and sequence chronostratigraphy of a "mid"-Cretaceous shallow-water carbonate succession of the Apulia Carbonate Platform from the northern Murge area (Apulia, southern Italy). Facies, 58, 17-36.

Tondi E., Piccardi L., Cacon S., Kontny B. \& Cello G. (2005) - Structural and time constraints for dextral shear along the seismogenic Mattinata fault (Gargano, southern Italy). Journal of Geodynamics, 40, 134-152.

Tondi E., Cilona A., Agosta F., Aydin A., Rustichelli A., Renda P. \& GiUnTA G. (2012) - Growth processes, dimensional parameters and scaling relationships of two conjugate sets of compactive shear bands in porous carbonate grainstones, Favignana Island, Italy. Journal of Structural Geology, 37, 53-64.

Tropeano M., Marino M. \& Pieri P. (1994) - Evidenze di tettonica disten siva plio-pleistocenica al margine orientale della Fossa bradanica l'Horst di Zagarella. Il Quaternario, 7, 597-606.

Tropeano M., Pieri P., Moretti M., Festa V., Calgnile G., Del Gaudio V. \& PIERI P. (1997) - Tettonica quaternaria ed elementi di sismotettonica nell'area delle Murge (Avampaese Apulo). Il Quaternario, 10, 543-548.

Turco E., Macchiavelli, C., Mazzoli S., Schettino A., Pierantoni P.P. (2012) - Kinematic

evolution of Alpine Corsica in the framework of Mediterranean mountain belts. Tectonophysics 579, 193-206.

Vezzani L. (1967) - I depositi plio-pleistocenici del litorale ionico della Lucania. Atti Acc. Gioenia Sc. Nat., 18, 159-180.

VIDEPI PRoJect: www.unmig.sviluppoeconomico.gov.it

Vlahović I., Tišluar J., Velić I. \& Matićec D. (2005) - Evolution of the Adriatic Carbonate Platform: Palaeogeography, main events and depositional dynamics. Palaeogeography, Palaeoclimatology, Palaeoecology, 220, 333- 360.

Zambrano M., Tondi E., Korneva I., Panza E., Agosta F., Janiseck J.M. \& Giongioni M. (2015) - Fracture properties analysis and discrete fracture network modelling of faulted tight limestones, Murge Plateau, Italy. Italian Journal of Geosciences, 135, 55-67. 